"professors" in the United States: are one hundred and fifty of them active investigators? The time seems remote when every American professor will be expected to be also an investigator; but among us is a little band of men who have before them the model of Germany, and who are working earnestly for the intellectual elevation of their country. Taeir first object is necessarily to render $r z-$ search more important in public estimation, and so to smooth the way for a corps of professional investigators. Every thoughtful person must wish success to the attempt.

\section{THE GEODETIC CONGRESS}

THE most generally interesting part of the proceedings of the Geodetic Conference which has been sitting at Rome during the past week is that connected with the selection of a common first meridian.

The report of the Permanent Committee of the International Geodetic Association recommends to the Conference the general acceptance of the meridian of Greenwich; it was referred to a Special Committee composed of one representative for each of the following-England, the United States, Germany, Italy, France, and Hamburg. The report concludes thus :-

"We terminate our report by proposing to the Assembly the following resolutions:-

"The seventh General Conference of the International Geodetic Association, held at Rome, and in which representatives of Great Britain, together with the directors of the principal astronomical and nautical almanacs, and a delegate from the Coast and Geodetic Survey of the United States have taken part, after having discussed the questions of unification of longitudes by the adoption of an initia! meridian, and of the unification of time by the adoption of a universal hour, have come to the following conclusions :-

"Firstly, that the unification of longitudes and of hours is as equally desirable in the interests of science as in those of navigation, commerce, and international communication. The scientific and practical utility of this reform considerably outweighs the sacrifices and the trouble of arrangement to which it will put the minority of civilised nations. It should, therefore, be recom. mended to the Governments of all the States interested that it may be arranged and confirmed by an International Convention, so that henceforth one and the same system of longitudes may be employed in all the astronomical and nautical almanacs, in all the geodetic and topographical bureaux and institutes, and in all geographical and hydrographical charts.

"Secondly, that the Conference propose to the Governments to choose for the initial meridian that of Greenwich, inasmuch as that meridian fulfils, as a point of departure of longitudes, all the conditions required by science ; and that being already actually the most extensively used of all, it presents the greater probability of being generally accepted.

"Thirdly, That the longitudes should be reckoned from the meridian of Greenwich in the sole direction of from east to west, and from zero to $360^{\circ}$, or from zero to twenty-four hours; the meridians on the charts and th. longitudes in the registers should be indicated everywhere in hours and minutes of time, with liberty of adding the indication of the corresponding degrees.

"Fourthly, That the Conference recognises for certain scientific needs, and for the service of the great administrations of the means of communication, such as railways, steamship lines, telegraphs, and posts, the utility of adopting a universal hour, side by side with the local or national hours, which will necessarily continue to be employed in civil life.

"Fifthly, That the Conference recommends, as the point of departure of the universal hour and of cosmopolitan dates, the mean noon of Greenwich, which coincides with the instant of midnight or with the beginning of the civil day, situated at the twelfth hour, or at $180^{\circ}$, Greenwich. It follows that the universal time will correspond everywhere with the mean local time, reckoned from midnight, less twelve hours and the longitude of the place, and that the dates change at the antipodes of Greenwich.

"Sixthly, That it is desirable that those States which, in order to adhere to the unification of longitudes and of hours, will have to change their meridians, should adopt the new system of longitudes as quickly as possible in their observatories and official almanacs, in their geodetical, topographical, and hydrographical works, and in their new charts. As a means of transition it would be well that in new editions of old charts, on which it would be difficult to change the squares, the indications according to the new system should at least be inscribed alongside the enumeration of the old meridians.

"Seventhly, That these resolutions should be laid before the Governments and recommended to their friendly consideration with the expression of a hope that an International Convention confirming the unification of longitudes and of hours may be conclude 1 as quickly as possible by a special Conference."

The Report is signed by the president, General Ibanez, and the secretaries, Professors von Oppolzer and Hirsch, the latter being also the reporter.

The paragraph in Dr. Hirsch's report, in which, after considering the question of the choice of an initial meridian, he emphatically conveys the opinion of the Permanent Committee in favour of that of Greenwich, merits quotation :-

"It cannot be doubted that the problem should be solved in favour of the meridian of Greenwich. It is by far the most extensively used, and, from the geographical, nautical, astronomical, and cartographical points of view, best answers the two conditions required. In fact, the immense British Empire, with its $20,000,000$ of square kilometres and its $250,000,000$ of population, extends over all parts of the world. Its mercantile marine, numbering 40,000 ships, with a total of from $6,000,000$ to $9,000,000$ of tons, and an equipment of 370,000 men, surpasses in importance the ensemble of all other navies. It must also be added that a great many other countries, among which the most important in respect of their mercantile marine are the United States, Germany, Austria, and Italy, equally use the Greenwich meridian in navigation, whence it may be affirmed that 90 per cent. of the navigators throughout long voyages calculate their longitudes by the meridian of Greenwich."

The Report of the Special Committee on the above resolutions was read on the $22 n d$ before the general meeting of the Conference, and accepted, after a very animated debate.

Referring to the resolutions it is only requisite to state briefly that, according to the Times report, as sent back to the Conference by the Special Committee, they now stand as follows:-Numbers I, 2, 4, 6, and 7 were adopted by the Committee without alteration; the other two were modified, or rather abbreviated, and now read thus :-

"Thirdly, that the longitude should be reckoned from the meridian of Greenwich, in the sole direction of from west to east.

"Fiftbly, That the Conference recommends, as the point of departure of the universal hour, and of cosmopolitan date, the mean noon of Greenwich, which coincides with the instant of midnight, or with the beginning of the civil day, under the meridian situated at 12 hours, or $180^{\circ}$, from Greenwich; the universal hours to be counted from zero to 24 ."

To these seven resolutions the Special Committee have 
added two others. The first, inserted between numbers one and two of those referre 1 to, reads thus:-

"That, notwithstanding the great advantages which the general introduction of the decimal division of the quadrant for geographic and geodetic co-ordination, and the corresponding expressions for time, is destined to realise, scientifically and practically, reasons eminently sound appear to justify the passing by the consideration thereof in the great measure of unification proposed in the first resolution. Meanwhile, to satisfy at the same time important scientific considerations the Conference recommends on this occasion the extension, in multiplying and perfecting the necessary tables, of the application of the decimal division of the quadrant, at least for the great numerical calculations for which it presents inconte stable advantages, even if it be desired to preserve the old sexagesimal division for observations, maps, navigation, \&c."

The other, inserted between resolutions six and seven, is as follows :-

"The Conference hopes that, if the whole world is agreed upon the unification of longitudes and hours in accepting the Greenwich meridian as the point of departure, Great Britain will find in this fact an additional motive to take on her side new steps in favour of the unification of weights and measures, by joining the Metrical Convention of May 20, 1875."

The resolution as to the choice of the initial meridian was carried by 22 votes to 4 ; while Mr. Christie, supported by the French delegates, moved the substitution of Greenwich midnight for noon as the point of departure; this amendment was negatived by 20 votes to 8 . Finally, Dr. Hirsch made a motion, unanimously carried, to the effect that the Conference should request the Government of His Majesty the King of Italy to officially communicate the resolutions voted by the assembly to all the Governments, including those not represented at the Conference.

Among other reports read was one by Dr. Hirsch, on the works of precise spirit levelling carried out in different States during the last tbree years. Col. Perrier, one of the French delegates, recommended that those works should be continued, so as to connect the Atlantic with the Pacific, and to ascertain the difference of level between those two oceans. General Ibanez read a report on tidal studies with the mareograph. An interesting discussion followed as to the best means for obtaining the most exact results, and a proposal made by General Ibanez to exclude observations taken at times when the sea is agitated was accepted.

Col. Ferrero proposed to close the network of triangles around that basin of the Mediterranean of which Italy forms the eastern side, and invited France to connect the Algerian network with the Italian at Tunis as quickly as possible. Col. Perrier replied, giving assurances that France would commence the work next year, and then read his report upon the measure of bases and the instruments employed, which concluded with a request that the Geodetic Association would invite Germany to prevent the destruction of geodetic signals.

A Committee, composed of Col. Clarke on the part of England for Malta, Capt. Kalmar for Austria, Col. Perrier for France, and Capt. Magnaghi, Col. de Stefanis, and Prof. Pergoal for Italy, were charged with the establishing of an accord for the trigonometrical junction of Italy with France, and Austria and Sicily with Malta, and instructed to invite the co-operation of England in communicating differences of longitudes to be determined telegraphicélly between Malta and Bona, between Malta and Naples, between Naples and Corfu, \&c.

The honorary president of the Conference was General Baeyer, and the acting president Col. Ferrero, President of the Italian Geodetic Commission. Mr. Christie, the Astronomer-Royal, and Col. Clarke, R.E., represented
England at the Conference. The United States was represented officially by General Cutts of the Coast Survey, though Messrs. Hilgard and Peirce seem also to have been present.

\section{LARGE AND RUDE PALEOLITHIC IMPLEMENT}

I November, I88I, Miss Eleanor A. Crmerod, F.M.S. of Isleworth, found the remarkable instrument here illustrated, and kindly added it to my collection. It was found in the gravel and brick-earth thrown out of an excavation maje for the new Hounslow and London Railway, immediately south of Osteriey Park, near Isleworth. The excavation at this spot showed about three feet of brick-earth resting on eight feet of gravel, and at this depth the London clay was reached, a foot or two of which was exposed. The gravel showed horizontal seams
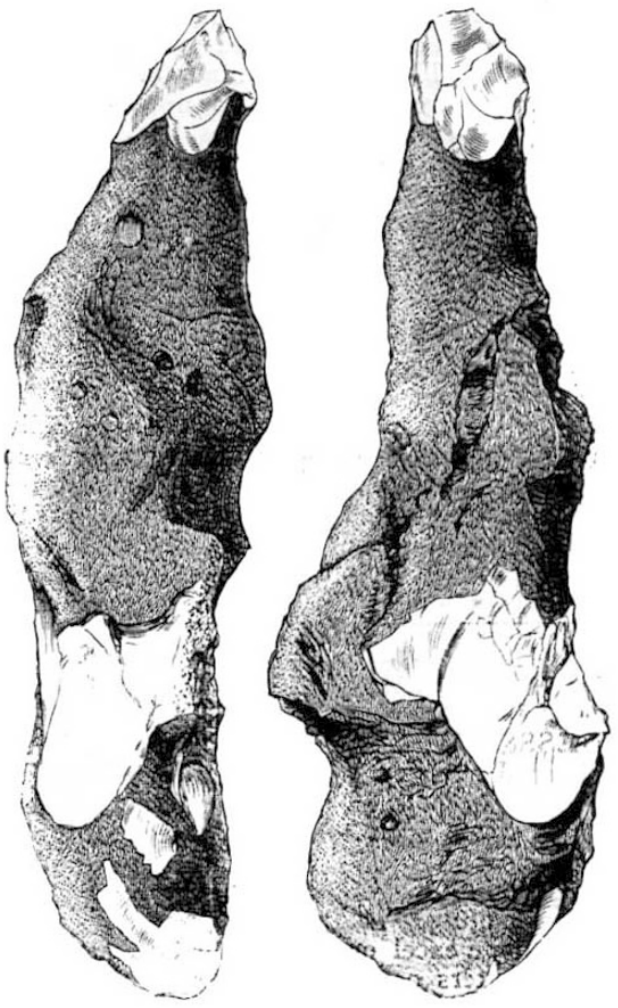

of fine sand, and agreed well with the well-known T hames gravel at Acton and Ealing.

The implement is engraved one-sixth actual size, and a front and side view are shown. It is exactly two feet in length, and weighs thirty-two pounds. It belongs to the gravel and sand, and is Palæolithic, as is proved by the ferruginous stains. Miss Ormerod, who saw that the flint had been trimmed to shape by human hands, took the instrument to be a huge club, the more attenuated end being possibly, she thought, designed for grasping in the hands; she also noticed that the more massive end was battered as if by use as a club. The more pointed end of this tool has been rudely but skilfully trimmed to a wedgelike point, and any one acquainted with flaking can see at a glance by referring to the illustration that the point is artificial. Towards the base at $\mathrm{A}$ (seen more distinctly on the right of left figure at same point) the battering is remarkably distinct. I do not think this battering has 